\title{
Key Trends and Application of Sustainability Rating Systems in the Hungarian Office Building Segment
}

\author{
Nikolett Deutsch, PhD \\ Corvinus University of Budapest, Hungary
}

Doi:10.19044/esj.2018.v14n26p216 URL:http://dx.doi.org/10.19044/esj.2018.v14n26p216

\begin{abstract}
Enhancing the sustainability of buildings and construction activities has become a key issue over the last decades. Since in the European Union, the construction industry is responsible for about the $40 \%$ of the total final energy consumption, around $36 \%$ of total $\mathrm{CO}_{2}$-emission, and $32 \%$ of total waste generation it is not surprising, that the ambitious energy and climate protection goals of the EU pose enormous challenges to the sector. Although in the relevant literature there is a lack of common understanding of what sustainable and green buildings are, several quantitative and qualitative methods regarding the assessment of buildings' sustainability, and approaches suitable for the examination of economic, social and environmental effects of buildings and the built environment have been emerged. The goal of this paper is to highlight the main principles and characters of green and sustainable buildings found in the literature, to summarize the key characteristics of the most important voluntary certification schemes applied in the European Union, and to present the current trends in the Hungarian Office market segment regarding the use of green certifications.
\end{abstract}

Keywords: Sustainable buildings, office market, green certification systems

\section{Introduction}

The design, construction, operation, and demolition of the built environment and buildings have several favorable and unfavorable environmental, economic and social impacts. From the economic point of view, the construction industry is responsible for 5-15\% of GDP, $5-10 \%$ of employment, and $45-50 \%$ of the gross fixed capital formulation in OECD countries (OECD, 2003, p. 20). Moreover, besides the various regional and local environmental impacts, residential and non-residential buildings and construction activities contribute significantly to global warming and climate change associated with human activity, to the use of fossil fuels and scarce resources. Moreover, building activities indirectly enhance the emergence of 
national security and the security of supply problems and generate a considerable amount of waste, while population growth and urbanization lead to the further expansion of the built environment.

In theory, increasing the sustainability characteristics of buildings can lead to many positive economic, social and environmental outcomes and represents a key value-adding opportunity (Hoffer, 2017). Besides the various environmental gains - such as the improvement of water, soil and air quality, waste reduction, climate protection, protection of biodiversity, natural and energy resources, the reduction of greenhouse gas emission - positive social and economic impacts can encompass the development and enhancement of energy and environmental awareness, the energy management competencies, the value and comfort of the buildings, the reduction of O\&M costs, energy consumption, the degree of energy dependency, the creation of new jobs and the support of the diffusion and learning rates of new technologies. Although, in practice, sustainable buildings and construction have to face numerous obstacles (see e.g. Azad \& Akbar, 2015). Of these challenges, the lack of customer interest, the continuous changes in the regulatory framework, the difficulties in accessing applicable technologies, non-standard solutions and material, the generally higher investment costs of sustainable buildings, the prolonged availability of savings, and the shortcomings in knowledge and information transfer associated with sustainable technologies and sustainable buildings are of particular importance (VTT, 2012). It is important to recognize that the diffusion of sustainable buildings and construction practices not only needs the elimination of these limiting factors or the existence and development of sustainable construction technologies, planning, construction and operational practices, but to elaborate and develop the widely accepted assessment aspects, indicators, methods, procedures and measures of sustainability in relation to buildings and construction activities which support that decisions taken at the different phases of the life-cycle are in harmony with the principles and dimensions of sustainable development (Deutsch, 2013).

The goal of this paper is to highlight the main principles and characters of green buildings and voluntary certification schemes based on the relevant literature and to present the current trends in the Hungarian Office market segment regarding the use of green certifications.

\section{Sustainable buildings - a term with several understandings}

In the relevant literature, a number of different terms with different content are used for describing buildings with better sustainable features such as green buildings (Bauer et al. 2010), energy-efficient buildings (Okeil, 2010), passive house (Feist et al., 2005), active house (Isaksson 2011), zero-emission 
buildings (Crawford, 2011), zero energy buildings (Marszal et al., 2011), sustainable buildings (Guy, 2010, Seyfang, 2010).

While the concepts of zero energy and energy-efficient building focus primarily on the minimization of the energy consumption throughout the whole life-cycle, the terms of green building and zero emission building capture the intention to minimize the negative environmental impacts of buildings throughout their life-cycle. Additionally, buildings accommodate a variety of social functions by providing space to live, work or entertain, etc. and in fact, their existence and condition have an impact on our health (see. ), comfort, and security, besides the close relationship between the construction industry and the economic and natural environment. Consequently, sustainable buildings, architectural and construction solutions must meet performance, functional, economic and at the same time social needs and expectations towards buildings and have minimal unfavorable environmental impacts over their lifespan. Therefore, a construction project or a building can only be regarded as sustainable if the economic, social and environmental dimensions of sustainable development are considered simultaneously during the design, construction, operation and demolition phases of its life-cycle (Szabó, 2017; Berényi, 2014, 2015).

Despite the fact that there is a lack of consensus on the definition of green and sustainable buildings and construction, indeed, these terms are often used interchangeably in the relevant literature, some authors attempt to clarify the main principles of green and sustainable buildings. The most cited articles and publications (Barnett \& Browning, 1995; IEA-OECD, 2001; Kilbert \& Grosskopf, 2005; Deutsche Bank, 2010; Lützkendorf, 2010) agree that the buildings simultaneously satisfying the social, economic and environmental aspects of sustainable development, are designed to

- be integrated with local ecosystems, weather and climatic conditions,

- be durable with long planned service lifetime,

- support the protection, appropriate and efficient use of land, water, energy, and other natural, agricultural, cultural, archaeological resources and raw materials over the total life-cycle of building blocks,

- support waste minimization over the full life-cycle,

- support the conservation of plants, animals, endangered species, and natural habitats,

- have minimal adverse environmental, social and health direct and indirect impacts over the total life-cycle of buildings,

- have high functionality assured by the use of integrated design methods, systematic approach, and the involvement of stakeholders,

- ensure the maximum use of passive design and renewable energy resources, 
- ensure the protection of aesthetic, artistic and cultural aspects

- ensure adequate indoor environment regarding the thermal, acoustic, and visual comfort and indoor air quality,

- ensure the consideration of total life-cycle cost in order to guarantee that the construction and operation of the building are economical,

- ensure recyclability and closed-loop material systems,

- ensure the ease of operation and maintenance activities, and to

- strengthen local economies and communities.

\section{Popular voluntary sustainable certification schemes in the EU}

Bragança et al. (2010) highlight that three types of sustainability assessment methodologies have emerged in the building industry: 1) Performance-Based Design, 2) Life-cycle Analysis systems, and 3) Sustainability rating systems.

Performance-based design and simulation tools support design professionals to predict and define the expected performance of new or retrofit buildings in the absence of invoices and/or measuring instruments. Performance-Based design and simulation methods allow to transform the functional needs of buildings into performance requirements and through the process of assessment, gap-analysis, and validation the most appropriate solutions can be found. By using these tools and methods, ecological and economic impacts of buildings can be considered parallel (Häkkinen et al., 2002; Szigeti \& Davis, 2005).

Life-cycle analysis methods are generally used in the studies and publications analyzing the total life-cycle environmental impacts of buildings, building materials and/or elements. While some authors (e.g. Marszal \& Heiselberg, 2011; Ramesh et al., 2012; Scheuer et al., 2003) focus on the potential application of LCA methods in the construction industry, some researchers (e.g. Banaitiene et al., 2008; Blengini, 2009; Lee et al., 2009) deal with the specialties and difficulties of each phase of the life-cycle, others (e.g. Crawford et al., 2006; Guardigli et al., 2011) aim at comparing the total lifecycle impacts of traditional and energy-efficient solutions. Furthermore, some studies explore the possibilities of further development of the LCA methodology and the use of software solutions (Erlandsson \& Borg, 2003; Verbeeck et al., 2010; Iyer-Raniga \& Wong, 2012).

Sustainability rating systems applied for building products support the qualitative and quantitative analysis of the environmental, social and economic impacts associated with buildings, and allocate points or scores to the various aspects of sustainability and according to the aggregation the formal rating systems assign sustainability scores or points to buildings. 
In the European Union, besides the mandatory EPC certification scheme required by the EPBD, some member states developed their own certification systems. Today, around 22 voluntary sustainable certification schemes are in use in the EU, and based on the current data on the number of certifications for non-residential buildings, it can be stated, that the most widely used national rating systems are the British BREAM (Building Research Establishment Environmental Assessment Method), the American LEED (Leadership in Energy and Environmental Design), the relatively young German DGNB (Deutsches Gütesiegel Nachhaltiges Bauen) and the French HQE (Hauté Qualité Environmentale) systems. Main elements and features of these certification systems are summarized in Table 1.

Besides the sustainability assessment of buildings, these certification systems support the design of new buildings and redesign existing buildings that meet the principles of sustainability. For all four rating systems, the scoring and evaluation process is based on national legislation, local conditions, and the environmental, legal and economic context. The evaluation processes of models are similar, as each system defines a maximum score or value (100 points, or 100\%) that can be achieved by the given building; indeed extra points can be also obtained for the most important aspects. In terms of application areas, each certification system uses different measurement and evaluation criteria for examining different types, i.e. residential, nonresidential, urban, and age, i.e. existing, new, of buildings (Nolte, 2010). It can be also stated, that a common feature of these certification systems is that the assessment of the performance of buildings and the life-cycle impacts of buildings are evaluated by the measures of site selection, energy, water and resource usage, indoor environment, and management issues. For the evaluation of the design phase of buildings' life-cycle, the sub-indicators of site selection and transportation issues, i.e. the availability of buildings (options for public and private transport), the availability of local services, the ecological value of the site, and the impacts on the landscape are examined. Energy utilization plays a significant role in all four assessment systems. Within this category, the use of renewable-based energy technologies, energyefficient equipment and tools, lighting, heating and cooling systems of buildings, the type of insulation used, energy-related aspects of building location, and the $\mathrm{CO}_{2}$-emission associated with energy consumption represent the main sub-indicators. Regarding the assessment of indoor environment, visual, acoustic, thermal comfort, ventilation, and indoor air quality are evaluated. Sustainability assessment of material and resource utilization during the construction phase is common in all certification systems, moreover, waste management issues and recycling potentials are important aspects in BREEAM and DGNB systems. However, while in the DGNB system the minimization of water usage is the key sub-indicator for water 
management, the certification systems of HQE, LEED and BREEAM also consider rain-water usage. Within the management aspects, besides the assessment of the use of traditionally considered sustainability design methods, the DGNB certification system measures the total life-cycle costs of buildings, LEED, BREEAM and HQE models focus on the assessment of the social and environmental impacts of buildings.

Table 1. Comparison of the key assessment systems used globally in the construction

\begin{tabular}{|c|c|c|c|c|}
\hline ASPECTS & BREEAM & LEED & DGNB & HOF \\
\hline Country of origin & UK (1990) & USA (1998) & $\begin{array}{c}\text { Germany } \\
\text { (2008) }\end{array}$ & France (2002) \\
\hline \multicolumn{5}{|c|}{ Scoring } \\
\hline $\begin{array}{c}\text { Maximum } \\
\text { available score }\end{array}$ & $100 \%(+10 \%)$ & $\begin{array}{c}100 \mathrm{p}(+10 \\
\text { point })\end{array}$ & $\begin{array}{c}100 \% \\
\text { (+extra) }\end{array}$ & $100 p$ \\
\hline Scoring & $\begin{array}{c}\text { Outstanding } \\
\text { Excellent } \\
\text { Very good } \\
\text { Good } \\
\text { Passable } \\
\text { Unclassified } \\
\end{array}$ & $\begin{array}{l}\text { Platinum: } 80 p \\
\text { Gold: } 60-79 p \\
\text { Silver:50-59p } \\
\text { Certified: } 40- \\
\text { 49p }\end{array}$ & $\begin{array}{c}\text { Gold: } 80 \% \\
\text { Silver: } 65- \\
79,9 \% \\
\text { Bronze: } 50- \\
\quad 64,5 \%\end{array}$ & $\begin{array}{c}\text { Exceptional } \\
\text { Excellent } \\
\text { Very good } \\
\text { Passable }\end{array}$ \\
\hline \multicolumn{5}{|c|}{ Key categories } \\
\hline International & Yes & Yes & No & Yes \\
\hline Urban & Yes & Yes & No & No \\
\hline Residential & Yes & Yes & No & Yes \\
\hline Non-Residential & Yes & Yes & Yes & Yes \\
\hline Main aspects & $\begin{array}{l}\text { Management } \\
\text { Health \& well } \\
\text { being } \\
\text { Energy } \\
\text { Transport } \\
\text { Water } \\
\text { Materials } \\
\text { Waste } \\
\text { Land use and } \\
\text { ecology } \\
\text { Pollution } \\
\text { Innovation }\end{array}$ & $\begin{array}{c}\text { Sustainable site } \\
\text { Water efficiency } \\
\text { Energy \& } \\
\text { Atmosphere } \\
\text { Materials \& } \\
\text { Resources } \\
\text { Indoor } \\
\text { environmental } \\
\text { quality } \\
\text { Innovation and } \\
\text { design process } \\
\text { Regional priorities }\end{array}$ & $\begin{array}{c}\text { Ecological } \\
\text { quality } \\
\text { Economic } \\
\text { quality } \\
\text { Socio- } \\
\text { cultural } \\
\text { quality } \\
\text { Site use } \\
\text { Process } \\
\text { quality }\end{array}$ & $\begin{array}{c}\text { Eco- } \\
\text { construction } \\
\text { Eco- } \\
\text { management } \\
\text { Comfort } \\
\text { Health }\end{array}$ \\
\hline $\begin{array}{l}\text { Issued by } 2014 \text { in } \\
\text { the Europe }\end{array}$ & $\begin{array}{c}7829(80 \% \text { in } \\
\text { the UK) }\end{array}$ & 663 & 487 & $\begin{array}{l}1793 \text { (over } \\
90 \% \text { in } \\
\text { France) } \\
\end{array}$ \\
\hline
\end{tabular}

Source: own edition, based on RICS (2011), Nolte (2010), Deutsche Bank (2010) and EC (2014a)

Significant differences can be observed between the weights assigned to the indicators used by these certification schemes. For example, while in the LEED system the focus is mainly on the use of energy, water, and raw materials and on the selection of the site, and in the DGNB system, process management, comfort, energy and water usage, and the economic impacts of 
the buildings are considered to be the most important aspects, BREEAM gives the most weight on the environmental performance of materials and products.

\section{Key trends in the Hungarian Green Office Market and the use of Green certification systems}

After the financial crisis of 2008, the Hungarian construction industry has had to experience nearly a decade-long downturn. However, based on the data published by the Hungarian Central Statistical Office (hereinafter referred as $\mathrm{KSH}$ ) in January 2018, the volume of construction sector output rose by 43.2 percent compared to the corresponding period of the previous year, while in 2017 the volume of construction sector output grew by $29.6 \%$ year-on-year, from which the construction of buildings increased by $27.0 \%$ partly due to the growth of the construction of industrial, residential, cultural and educational buildings (KSH, 2018).

Regarding the Hungarian office market segment, it should be emphasized, that the modern office market only exists in Budapest and its vicinity. While office spaces of different sizes and standards are available in the county seats and larger cities of Hungary, these cannot be compared to the capital's supply neither in quality or in quantity, moreover, new developments are concentrated mainly on Budapest. Offers available on the large search portals specialized to the Hungarian office segment and the industry analysis regularly published by the key market players, such as Cushman \& Wakefield, CBRE, Colliers International, or Eston, are clearly capital-centric, indeed, in the international studies, Budapest also gains a superior role. Although due to Hungary's monocentric and capital-oriented structure, no significant change is expected in this trend in the near future, high-class office spaces with internationally comparable sizes are now available in some of the largest cities of the country, like Győr, Szeged or Debrecen.

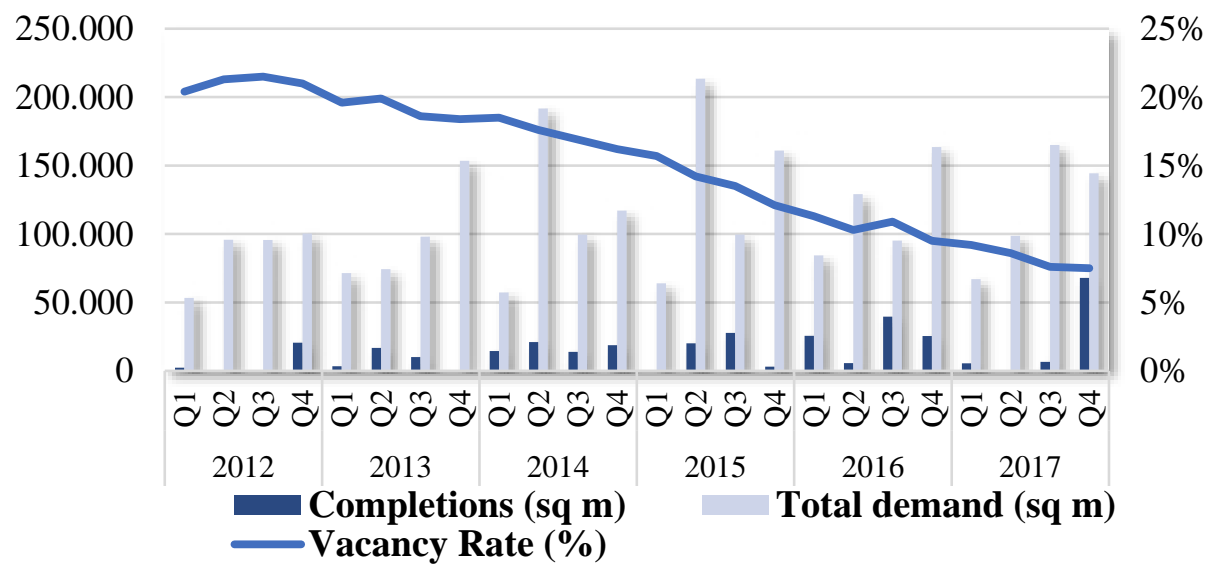

Figure 1. Supply, demand, and vacancy

Source: own edition, based on the annual reports of BRF (2012-2017) 
According to the data published by The Budapest Research Forum (hereinafter the BRF) and illustrated by Figure 1, in the office market segment of Budapest, the annual supply increased from $22951 \mathrm{~m}^{2}$ to $96274 \mathrm{~m}^{2}$, from 2012 to 2016 reaching its highest level. Regarding the annual demand (including owner occupation), a significant increase (55.97\%) can be observed between 2012 and 2015, when the volume of signed transactions achieved $538055 \mathrm{~m}^{2}$, and after a small drop in 2016, the volume of total leasing activity started to grow again by $0.56 \%$. During the period under review, the office vacancy rate decreased by 2.70 percentage points per annum and reached its historical minimum of $7.5 \%$ in 2017. Currently, the total modern office stock in Budapest added up to $3415550 \mathrm{~m}^{2}$ consisting of $2754595 \mathrm{~m}^{2}$ speculative office space and $660950 \mathrm{~m}^{2}$ owner-occupied space. Despite the fact that labor shortages and increasing construction costs put pressure on the development market, the annual completion volume reached $79920 \mathrm{~m}^{2}$ in 2017 which indicates a 17\% drop compared to 2016 (BRF, 2017, p.1).

Leasing activity is motivated mainly by the growth of the Shared Service Center and Business Process Outsourcing sectors. The split of annual leasing activities visualized in Figure 2, indicates that during the period under review, the share of new lease agreements remained stable, while expansions decreased from $26.07 \%$ to $10.14 \%$. The share of renewals in annual leasing activity in 2017 amounted to $28.94 \%$ which is 10.07 percentage points lower than in 2012.

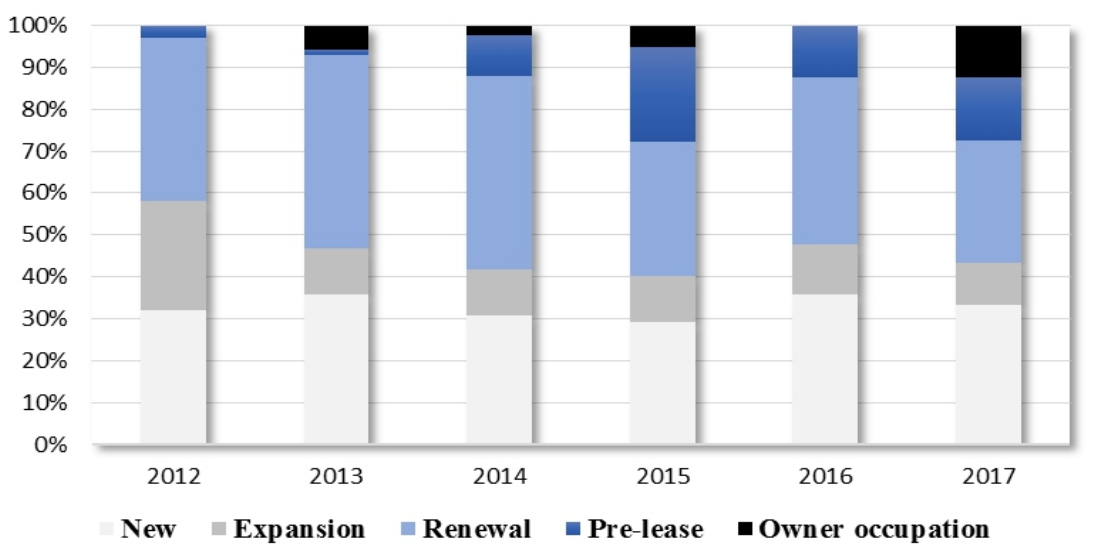

Figure 2. Split of office demand

Source: own calculation, based on BRF (2012-2017)

The office market of Budapest can be divided into 8 sub-markets, i.e. Central Buda, Central Pest, North Buda, South Buda, Non-Central Pest, Váci út Corridor, Periphery with unequal weights. Due to its location and its excellent infrastructure, the best performing sub-market was Váci út Corridor both in terms of development and leasing activities, followed by South Buda, 
Non-Central Pest and North Buda sub-markets (Colliers International, 2018, p. 2.). Average headline rent levels differ significantly by sub-markets and building categories. In prime locations, the average headline rent increased by around 5-10\% from 2016 to 2017. Regarding "Grade A" properties the lowest average rent was observed in the Periphery sub-market $\left(10.00 € / \mathrm{m}^{2} / \mathrm{month}\right)$, which were followed by the Váci Corridor $\left(15.25 € / \mathrm{m}^{2} / \mathrm{month}\right)$, Central-Bud $\left(16 € / \mathrm{m}^{2} /\right.$ month) and Central Business District (22€/ $\mathrm{m}^{2} /$ month) sub-markets (Cushman \& Wakefield, 2017). It is also worth to note that based on the calculations of Cushman \& Wakefield (2017) the average gross prime office yields in the last quarter of 2017 were in the range of $6.00 \%$ (Periphery submarket) - 8.5\% (Central Business District sub-market).

Although the market for voluntary building certification schemes is relatively young, in the Hungarian office building sector, green building certifications have become a market standard. Between 2012 and 2017, the share of green certified office buildings in the total modern office stock in Budapest grew from $7.5 \%$ to $32.7 \%$. However, it is worth to note, that the ratio is much lower - around 13\% in 2017 - if total building stocks are considered (Colliers International, 2018).

The number and office areas of green-certified buildings in Budapest have been constantly growing during the last five years as it is indicated in Figure 3. The number of green-certified office buildings has quadrupled during the period under review, and the total office area of green-certified buildings achieved $1201000 \mathrm{~m}^{2}$ in 2017.

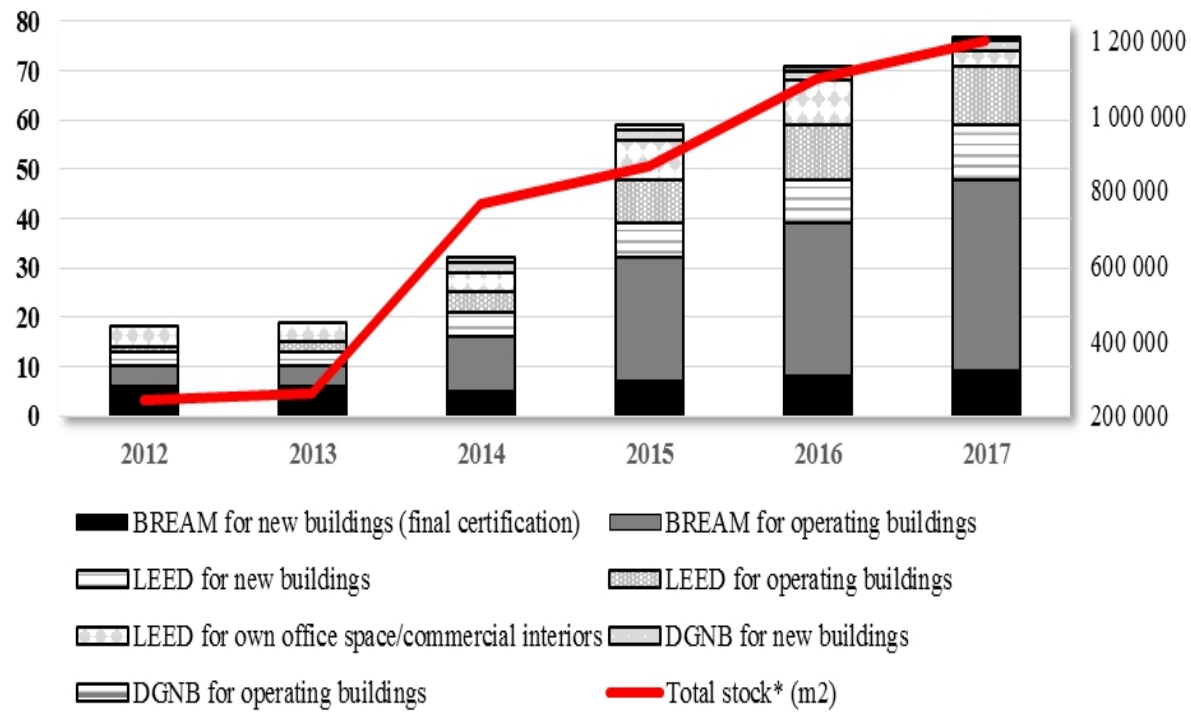

Figure 3. Green certified buildings and office area in Budapest Source: own calculations based on the data sets of BREAM, LEED and DGNB databases and the annual reports of Colliers International (2012-2018) 


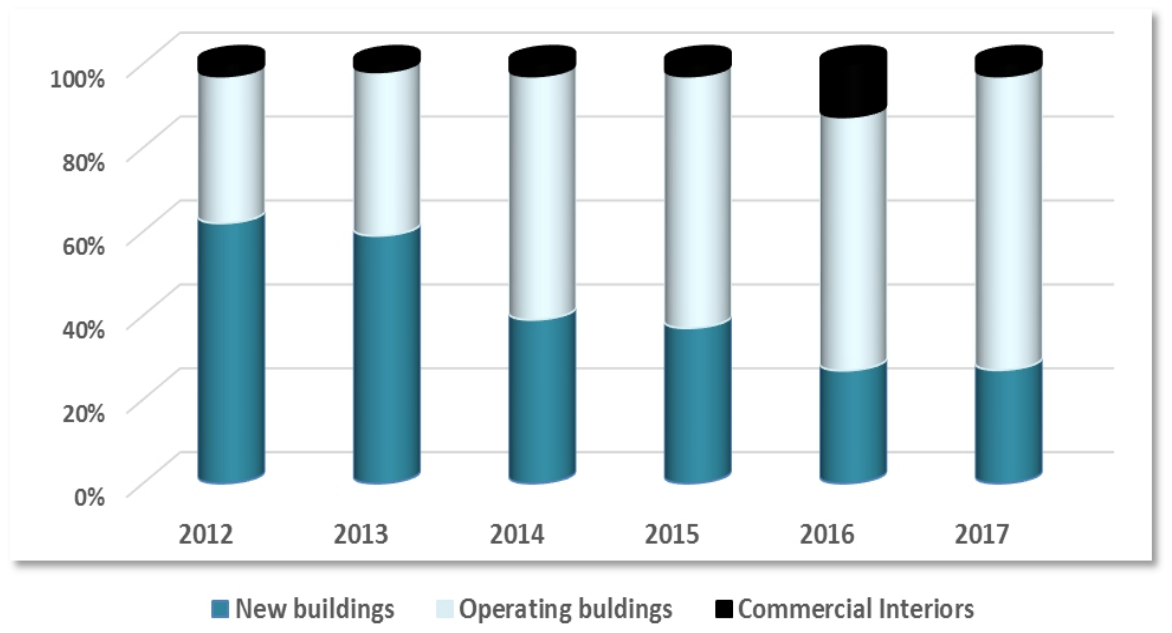

Figure 4. Ratio of green certifications on the Budapest office market Source: own calculations based on the data sets of BREAM, LEED and DGNB databases and the annual reports of Colliers International (2012-2018)

The two widely used certification systems in the office sector in Hungary are the BREAM and LEED systems, however, in 2014 three office buildings were certified under the DGNB system. Regarding the market shares of these certification systems, BREAM has had a dominant position in the Hungarian office market for existing building and new construction certifications. In 2017, BREAM in-use certifications accounted for around 44\% of the total green office stock, and BREAM new construction certifications had a $23 \%$ share in the total green office market of Budapest. The market share of LEED in-use and new construction certifications achieved a sum of $41 \%$ in 2017. If one examines the trends of certification activities, it can be concluded, that in the last few years the majority of the certifications were existing buildings, while between 2016 and 2017 the share of new building certifications in total green office certifications stabilized around 27\% (see Figure 4.).

The analysis and forecasts of BRF (2017), CBRE (2017) and Colliers International (2018, p. 1) highlight, the dynamic of the use of green office certifications is likely to continue since around $464000 \mathrm{~m}^{2}$ of office areas are under development in Budapest from which around $350000 \mathrm{~m}^{2}$ is expected to be in the pipeline for 2018, indicating that in the following year the green certified office space will increase by around $28.92 \%$.

Beside the green certifications of existing and newly constructed offices, a number of retail and industrial properties has gained green certification over the last years and green certification activities now extend beyond the capital city and its borders. Pallas Athéné office building obtained in-use BREAM certifications in the Asset management and Building Management categories in 2015. In 2013 Árkád Szeged, in 2017 Árkád Pécs acquired DGNB new- 
retail and the extension of Auchan Soroksár obtained BREAM interim certification. Regarding the service sector, the FTC and MTK Stadiums of Budapest and the Four Points by Sheraton Kecskemét achieved certification under the LEED new construction scheme in 2014 and 2017 respectively. The number of certified industrial properties has increased considerably between 2012 and 2017 since the Henkel's factory in Körösladány achieved DGNB Silver rating in 2012, the ProLogis Park Sziget in Hegyeshalom was certified under BREAM new construction (BREAM, LEED and DGNB databases, Colliers International (2018)).

According to the data sets of BREAM, LEED and DGNB systems available via the internet, there was a sum of 129 valid green building certifications in the country in 2017. Figure 5 summarizes the distribution of these certifications by key certification categories of the rating systems. Based on the Figure, it can be concluded that 82 out of the 129 were BREAM certifications awarded in five categories (for existing: Buildings asset management certifications, Building Management certifications and Occupier Management certifications, for new constructions: Interim and Final certifications).

Regarding the number of green building certifications by levels presented by Figure 6,3 out of the 6 buildings with DGNB certifications obtained the Platinum rating, $58.54 \%$ of the buildings with LEED certification achieved the Gold rating, while $81.79 \%$ of the buildings certified under the BREAM system gained Very Good or Excellent rating.

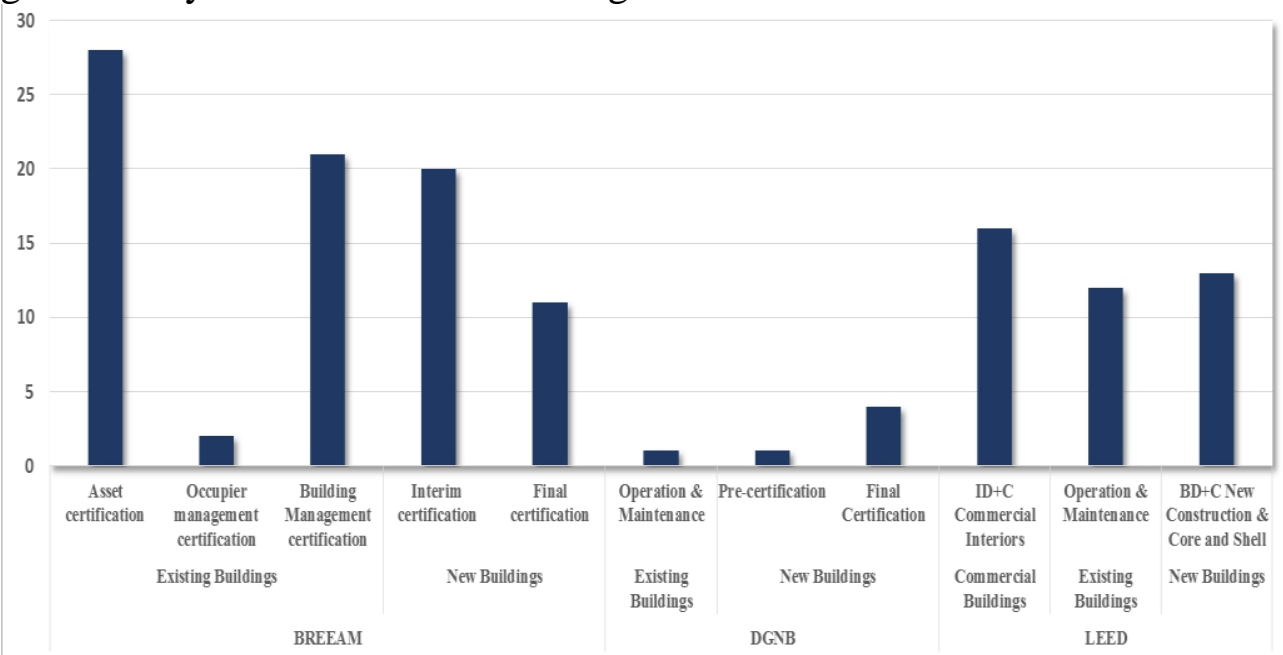

Figure 5. Green certified buildings in Hungary in 2017

Source: own calculations, based on the data sets of BREAM, LEED and DGNB databases 


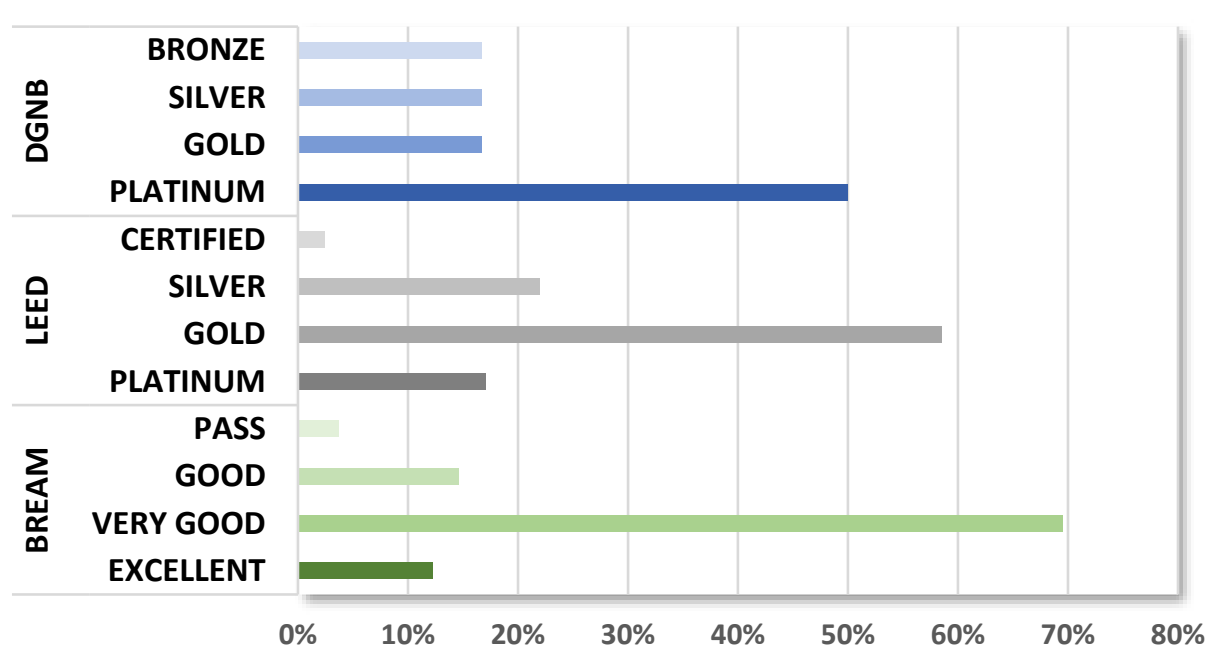

Figure 6. Share of rating categories in all building types, in 2018

Source: own calculations based on the data sets of BREAM, LEED and DGNB databases

\section{Conclusion}

The commitment of the European Union and its Member States towards the goals of sustainable development has a significant impact on the construction industry as well. Over the last decade, different procedures and methods have emerged which can be applied for the sustainability assessment of buildings. According to the EC (2014b, p. 25), member states of the EU can be divided into two main categories: countries where voluntary certification schemes have been developed (e.g. France, UK, Germany, Czech Republic, Italy, Portugal, Spain, Austria, Belgium, Finland, Denmark, Sweden, Belgium) and countries where the mandatory EPC certification scheme system required by the EPBD is used to a large extent. Based on their market shares, BREEAM, LEED, DGNB, and HQE are the market leader in voluntary schemes in the European Union. Although the market for voluntary building certification schemes is relatively young in Hungary, the rate of green office buildings in the total modern Budapest office stock has increased fourfold between 2012 and 2017. The two widely used certification systems are BREEAM and LEED. According to the current trends, green building certifications have become a market standard in the Hungarian Office market segment, moreover, shopping centers, malls and other public buildings with sustainable certifications have been also appearing.

\section{References:}

1. Azad, S., \& Akbar, Z. (2015). The impediments in construction of sustainable buildings in Pakistan. European Scientific Journal,11(29), 369-379. 
2. Banaitiene, N., Banaitis, A., Kaklauskas, A. \& Zavadskas, E. K. (2008). Evaluating the life cycle of a building: A multivariant and multiple criteria approach. Omega, 36(3), 429-441.

3. Barnett, D. L. \& Browning, W. D. (1995). A Primer on Sustainable Building. Snowmass, CO: Rocky Mountain Institute

4. Bauer, M., Mösle, P. \& Schwarz, M. (2007). Green Building Guidebook for Sustainable Architecture. Berlin: Springer-Verlag

5. Berényi, L. (2015). Social aspects and challenges of renewable energy usage. In: Ortiz W, Somogyvári, M., Varjú, V., Fodor, I. \& Lechtenböhmer, S. (Eds). Perspectives of Renewable Energy in the Danube Region. 357 p.: Pécs, Magyarország, 2015.03.26-2015.03.27. Pécs: Institute for Regional Studies, Centre for Economic and Regional Studies, Hungarian Academy of Sciences. 2015. pp. 81-87.

6. Berényi, L. (2014). A környezetmenedzsment feladatai és lehetöségei. Budapest: Publio Kiadó.

7. Blengini, G. A. (2009). Life cycle of buildings, demolition, and recycling potential: A case study in Turin, Italy. Building and Environment, 44(2), 319-330.

8. Bragança, L., Mateus, R. \& Koukkari, H. (2010). Building Sustainability Assessment. Sustainability, 2, 2010-2023.

9. BREEAM database. Retrieved from: http://www.greenbooklive.com/search/scheme.jsp?id=202, Accessed: 14.05.2018.

10. BRF (2017). Office market report summary 2017 Q4. Retrieved from http://www.colliers.com/hu-hu/hungary/insights/research/brf-marketreports, Accessed: 14.05.2018.

11. BRF quaterly reports database. Retrieved from http://www.colliers.com/hu-hu/hungary/insights/research/brf-marketreports, Accessed: 14.05.2018.

12. CBRE (2017). Budapest Office market. Retrieved from: http://admin.officego.hu/assets/res/piacelemzes/Office\%20Market\%2 0View.pdf, Accessed: 14.05.2018.

13. Colliers International (2018). Green building certification. Retrieved from:

http://www.colliers.com/-

/media/files/emea/hungary/research/market-

reports/2018/green_mr_2018_hungary_eng.pdf?la=en-gb, Accessed: 14.05.2018.

14. Colliers International (2017). Zöld épület minősítés. Retrieved from: http://www.colliers.com/-/media/files/emea/hungary/research/marketreports/2017/green_hun_2017_final.pdf?la=hu-hu,

Accessed: 14.05.2018. 
15. Colliers International (2016). Zöld épület minősítés. Retrieved from: http://www.colliers.com/-/media/files/emea/hungary/research/marketreports/2015/2015-h2/green\%20report_h2_2015_hun.pdf?la=hu-hu, Accessed: 14.05.2018.

16. Colliers International (2015): Zöld épület minősítés. Retrieved from: http://www.colliers.com/sitecore/shell///media/files/emea/hungary/research/marketreports/2015/green_mr_2015_hun.pdf, Accessed: 14.05.2018.

17. Colliers International (2013): Fenntartható épületek. Retrieved from: http://content.colliers.com/sitecore/login, Accessed: 14.05.2018.

18. Crawford, R. H. (2011). Towards a comprehensive approach to zeroemissions housing. Architectural Science Review, 54(4), 277-284.

19. Crawford, R. H., Treloar, G.J., Fuller, R.J. \& Bazilian, M. (2006). Lifecycle energy analysis of building integrated photovoltaic systems (BiPVs) with heat recovery unit. Renewable and Sustainable Energy Reviews, 10(6), 559-575.

20. Cushman \& Wakefield (2017). Office Market Snapshot. 2017. Retrieved from: http://www.cushmanwakefield.hu/hu-hu/researchand-insight/hungary/hungary-office-snapshot, Accessed: 14.05.2018.

21. Deutsch, N. (2013). Épületek fenntarthatósági értékelésének lehetséges módszerei. Marketing \& Menedzsment, Különszám, 1-11.

22. Deutsche Bank (2010). Green Buildings: A niche becomes mainstream. Deutsche Bank Research Publication, Retrieved from: http://www.dbresearch.com, Accessed: 09.05.2013.

23. DGNB database. Retrieved from: https://www.dgnb-system.de/en/, Accessed: 10.05.2018.

24. EC (2014a). Voluntary energy performance certification schemes database. Retrieved from: https://ec.europa.eu/energy/en/eubuildings-factsheets-topics-tree/voluntary-energy-performancecertification-schemes, Accessed: 11.07.2018.

25. EC (2014b). Market study for a voluntary common European Union certification scheme for the energy performance of non-residential buildings. ENER/C3/2012-436. Rotterdam: Triple E Consulting.

26. Erlandsson, M. \& Borg, M. (2003). Generic LCA-methodology applicable for buildings, constructions and operation services-today practice and development needs. Building and Environment, 38(7), 919-938.

27. Feist, W., Schnieders, J., Dorer, V. \& Haas, A. (2005). Re-inventing air heating: Convenient and comfortable within the frame of the Passive House concept. Energy and Buildings, 37(11), 1186-1203.

28. Guardigli, L., Monari, F. \& Bragadin, M. A. (2011). Assessing environmental impact of green buildings through LCA methods: a 
comparison between reinforced concrete and wood structures in the European context. Engineering, 21, 1199 - 1206.

29. Guy, S. (2010). Pragmatic ecologies: situating sustainable building. Architectural Science Review, 53(1), 21-28.

30. Häkkinen, T., Huovila, P. \& Tattari, K.(2002) Eco-efficient building process, In: från International Conference of Sustainable Building (pp. 23-25).

31. Hoffer, I. (2017). Építőipari beruházási projektek értékelemzése. Presentation at Projektmenedzsment Szövetség Építési Tagozat, Budapest, 08.11.2017.

32. Isaksson, C. (2011). From a passive to an active house, WREC 2011, Retrieved from: http://www.ep.liu.se/ecp/057/vol8/007/ecp57vol8_007.pdf, Accessed: 26.03.2013.

33. Iyer-Raniga, U. \& Wong, J. P.C. (2012). Evaluation of whole life cycle assessment for heritage buildings in Australia. Building and Environment, 47, $138-149$.

34. Kilbert, C .J. \& Grosskopf, K. (2005). Radical sustainable construction: envisioning next-generation green buildings. Retrieved from: https://www.cce.ufl.edu/wpcontent/uploads/2012/08/WhitePaper-RSC06.pdf, Accessed: 24.08.2017.

35. KSH (2018). 35.0\% increase in the volume of construction output in December. Retrieved from: http://www.ksh.hu/docs/eng/xftp/gyor/epi/eepi1712.html, Accessed: 14.05.2018.

36. Lee, K., Tae, S. \& Shin, S. (2009). Development of a Life Cycle Assessment Program for building (SUSB-LCA) in South Korea. Renewable and Sustainable Energy Reviews, 13(8), 1994-2002.

37. LEED database. Retrieved from: https://www.usgbc.org/projects, Accessed: 14.05.2018.

38. Lützkendorf, T. (2010). How to BREAK the Vicious Circle of blame? The contribution of different stakeholders to a more sustainable built environment, In Abstract Book of Sustainable Building 2012 Brazil Conference, Wiley Publishing

39. Marszal, A. J. \& Heiselberg, P. (2011). Life cycle cost analysis of a multi-storey residential Net Zero Energy Building in Denmark. Energy, 36(9), 5600 - 5609.

40. Marszal, A. J., Heiselberg, P., Bourrelle, J. S., Musall, E., Voss, K., Sartori, I. \& Napolitano, A (2011). Zero Energy Building-A review of definitions and calculation methodologies. Energy and Buildings, 43(4), 971-979. 
41. Nolte, I. (2010). Comparison of worldwide certification systems for sustainable buildings, Longlife Project, Retrieved from: http://www.longlife-world.eu/res/dnl/en/20100201-LL$\% 20$ comparison\%20certification\%20systems.142.pdf, Accessed: 02.11 .2012 .

42. Okeil, A. (2010). A holistic approach to energy efficient building forms. Energy and buildings, 42(9), 1437-1444.

43. Ramesh, T., Prakash, R. \& Shukla, K. K. (2012). Life cycle approach in evaluating energy performance of residential buildings in Indian context. Energy and Buildings, 54, $259-265$.

44. RICS (2011). Going for "Green" Sustainable Building Certification Statistics Europe. Retrieved from: http://www.rics.org/sustainability, Accessed: 26.03.2013.

45. Scheuer, Ch., Keoleian, G.A. \& Reppe, P. (2003). Life cycle energy and environmental performance of a new university building: modeling challenges and design implications. Energy and Buildings, 35(10), 1049-1064.

46. Seyfang, G. (2010). Community action for sustainable housing: Building a low-carbon future. Energy Policy, 38(12), 7624-7633.

47. Szabó, L. (2017). Fejlesztési projektek fenntarthatósága. Köszeg; Szombathely:Felsőbbfokú Tanulmányok Intézete

48. Szigeti, F. \& Davis, G. (2005). Performance Based Building: Conceptual Framework, Retrieved from: http://www.pebbu.nl, Accessed: 11.02.2013.

49. Verbeeck, G. \& Hens, H. (2010). Life cycle inventory of buildings: A calculation method. Building and Environment, 45(4), 1037-1041.

50. VTT (2012). Sustainability and performance assessment and benchmarking of buildings, Final Report, Superbuilding Project. Retrieved from: https://www.vtt.fi/inf/pdf/technology/2012/T72.pdf, Accessed: 11.02.2013. 